\title{
医薬品開発におけるファーマコゲノミクスの現状と展望
}

\author{
玉 起 美 恵子
}

\section{Perspectives on the Current State of Pharmacogenomics in Drug Development}

\author{
Mieko TAMAOKI \\ Astellas Pharma Inc., 2-3-11 Nihonbashi-Honcho, Chuo-ku, Tokyo 103-8411, Japan
}

(Received July 10, 2008; Accepted October 21, 2008)

\begin{abstract}
Pharmacogenomics is expected to become one of the ways by which serious drug development problems can be broken down and solved. In fact, the field of pharmaceutical development seems to be using pharmacogenomics increasingly as a means of both drug selection (via genotyping) and proper dosage determination. Before pharmacogenomics can be put to practical use, however, scientific and technical issues must first be resolved, after which social and ethical issues must be addressed. In Japan, drug developers are preparing for the introduction of pharmacogenomics into clinical trials. As they anticipate the necessary revisions, they must keep in mind not only the differences between current practice and that including pharmacogenomics, but also international standards. Therefore, developers are discussing strategies for communicating the necessary changes to academic and regulatory parties in an attempt to obtain a consensus and smoothly implement these changes. A survey of the academic and regulatory parties revealed that there were concerns about what pharmacogenomic information should be obtained, who would have access to it, and how it should be transmitted. Since industry, academia, and the regulatory body all agree that pharmacogenomics need to be implemented in Japan, deeper discussion of the science, technology, regulation, and ethics relevant to this topic should be continued both domestically and internationally.
\end{abstract}

Key words— $—$ pharmacogenomics; drug development; perspective

\section{1.はじめに}

1991 年にヒトゲノムの解読が始まり，2001 年 2 月には Nature ${ }^{1)}$ 及び Science ${ }^{2)}$ にドラフト解読の結 果が公表され，2003 年 4 月に解読完了の宣言がな された.「21 世紀は生命科学の時代」と1998 年の 米国大統領教書で宣言されたようにゲノム科学の進 歩が生命科学を大きく発展させるのではないかとの 期待は大きい. 実際, ポストゲノムとしてプロテオ ミクスやバイオインフォマティクスなども進展し, 情報も整備されてきた。 また，コンビナトリアルケ ミストリーやハイスループットスクリーニングなど の創薬技術も進歩し，創薬のスピードアップや効率 化が期待された。しかしながら，ゲノム技術を始め とする技術面の目覚しい革新にも係わらず，1990 年代中頃から製薬企業の研究開発費は増大するもの の世界的に上市される新薬が減少するというイノ

アステラス製薬侏（テ103-8411 東京都中央区日本橋本 町 2-3-11)

e-mail: mieko.tamaoki@jp.astellas.com
ベーションギャップと呼ばれる現象がみられるよう になってきた.

ゲノム科学により創薬のターゲットの数が増え, 最先端のハイスループット技術の活用によりスク リーニングされる新規物質の数こそ増えたが，新薬 候補物質の $90 \%$ は臨床開発段階で開発中止に至 る.開発中止となる原因の $80 \%$ は有効性や安全性 であり，成功率を高める 1 つの手段として臨床試験 への組み入れ前の遺伝子検査に基づき候補物質のレ スポンダー及びノン・レスポンダーとなる可能性の 高い患者を特定すること，すなわちファーマコゲノ ミクスが有用ではないかと期待されている。さら に，臨床試験に必要な有効性の証明に必要な患者数 の減少, 開発期間の短縮やコスト削減にもつなが り, 臨床開発の成功に大きく貢献することができる.

最近の米国での調査では，副作用が原因で年間 10 万人以上が亡くなっており，副作用は入院疾患 の $5 \%$ を占めていることが明らかにされている. ${ }^{3}$ また，肝毒性や不整脈等の深刻な副作用は新薬の開 
発段階及び市販後における大きな問題である. 1990 年から 2004 年までの 15 年間に, 安全上の理由によ り 34 種類の医薬品が市場から撤退した. ${ }^{4)}$ 最近の例 としては troglitazone, cerivastatin, rofecoxib が知 られている，市場からの医薬品の撤退は製薬業界の みならず社会にとっても大きな損失である。深刻な 副作用に関係する遺伝的要因を特定できれば，これ らのいくつかの医薬品は市場からの撤退を免れたと 思われる. ${ }^{5-7)}$ 患者個人の遺伝情報に基づいた薬物 療法は，薬物応答性を改善するばかりでなく，副作 用の大幅な軽減を可能にすると考えられる.

2004 年 3 月，米国食品医薬品局（Food and Drug Administration； FDA）の報告書「Innovation or Stagnation-Challenge and opportunity on the critical

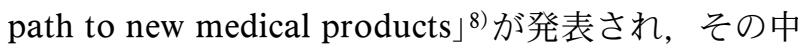
で，医薬品開発における現状と問題点が指摘されて いる，特に，医薬品開発における安全性と有効性の 評価手段の技術不足が，開発の失敗や長期化を招い ていると指摘している. 2006 年の「Innovation or Stagnation-Critical Path Opportunities Report $\rfloor^{99}$ 及 び「Innovation or Stagnation-Critical Path Opportunities List」 ${ }^{10)}$ では，疾患モデル動物の開発等とと もに予測性の高い新世代バイオマーカーを利用した 効率的な医薬品の創製と活用，疾病の診断への応用 を求めており，ファーマコゲノミクスに対する期待 が示唆されている。また，ファーマコゲノミクスが 注目される背景としてファーマコゲノミクスの開 発，応用の基盤が整備されてきたことも重要であ る。ファーマコゲノミクスの定義等は日米 EU 医薬 品規制調和国際会議（International Conference on Harmonization of Technical Requirements for Registration of Pharmaceuticals for Human Use; ICH) で 合意され，2008 年 1 月に厚生労働省医薬品局より 「ゲノム薬理学における用語集（E15）」についての 通知が出された. ${ }^{11)}$ これによるとファーマコゲノミ クスは Table 1 のように規定される.

2. 日本におけるファーマコゲノミクス研究の動 向の意識調査

日本では 1999 年 12 月にミレニアム・プロジェク トが閣議決定され，バイオテクノロジーによる健康 で安心できる高齢化社会の実現に向けた取り組みが 開始された。 ${ }^{12)}$ 製薬企業も 43 社がコンソーシアム を作り，薬物動態に関係する一塩基多型（single
Table 1. Definition of Terms

1. Pharmacogenomics (PGx) is defined as: The study of variations of DNA and RNA characteristics as related to drug response. (ゲノム薬理学 (PGx) は薬物応答と関 連する DNA 及び RNA の特性の変異に関する研究）

2. Pharmacogenetics (PGt) is a subset of PGx and is defined as: The study of variation in DNA sequence as related to drug response. (薬理遺伝学 (PGt) は PGx の一部であり, 薬物応答と関連する DNA 配列の変異 に関する研究)

3. A genomic biomarker is identified as: A measurable DNA or RNA characteristic that is an indicator of normal biologic processes, pathogenic processes, and/or responses to therapeutic or other intervention. (ゲノム バイオマーカーは正常な生物学的過程, 発病過程, 及 び／又は治療的介入等への反応を示す指標となる, DNA 若しくは RNA の測定可能な特性)

nucleotide polymorphism; SNP) の共同研究を実施 した. ${ }^{13)}$ 世界では 2001 年 2 月には Celera Genomics と国際 Human Genome Project がヒトゲノム塩基 配列のドラフト配列を発表したのをはじめとして次 々にゲノム研究の成果が公表されている。 その結 果，一部の熱心な研究者ばかりでなく厚生労働省等 の規制当局，製薬企業や診断薬・機器メーカー等の 医療関連企業，医療従事者，さらには一般の人々に もファーマコゲノミクスの知識が広まり，理解され 始めている.

実際，一般市民及び医療従事者，医療関連企業， 行政，アカデミアを対象としたファーマコゲノミク スに関する意識調査によると，日本においても，過 去数年間でファーマコゲノミクスに対する認識は進 んでいるが，一般市民及び診療の場においてはまだ 十分な理解が得られていない。治験を担当する企業 サイドでは，ファーマコゲノミクスの重要性は理解 しているが，その実現は相当先の話であると考えら れている。しかしながら，ファーマコゲノミクスに 臨床診療での効果，医薬品の有用性の向上などを期 待する人々が多いことは明らかである。一方で，フ アーマコゲノミクスの重要性は認めつつ，ゲノム情 報の悪用，説明用途以外の使用，個人情報の流用を 懸念されてきた。ファーマコゲノミクスの実用化に は倫理問題に取り組む必要があることが示唆されて いる. ${ }^{14-19)}$

ファーマコゲノミクスの実現は，その実現に貢献 
しようとする関係者の積極的な意思に係っている. 有益なファーマコゲノミクス研究を促進するために は，まず，研究の参加者に敬意を払い，人間の尊 厳，基本的自由，人権を保護する方法で研究が実施 される必要がある。研究のプロトコルは倫理審査委 員会によって承認され，公正な科学的判断を受ける 必要があり, 参加は個人の選択の自由, 機密性, プ ライバシーを尊重した非強制的かつ公平な方法で行 われるべきである。そして，企業は，法律，倫理規 範に従って試験を行う責任がある．ファーマコゲノ ミクス研究の背景, 目的, 倫理的な管理の枠組み等 について明確に示すとともに，参加者のプライバ シーを保護するために，記録，試料及びデータの収 集，処理，取扱い，保管等に関して，プロトコル及 び手順書を策定する必要がある。特に，プライバ シーの保護に関して，データ及び情報が保護される ことを保証すべきであり，試料及びデー夕の保護に 関する方針及び手順を確立し，試料及びデー夕の保 護レベル，保護のために採用する手段に関する情報 を参加者に提供すべきである.

また，企業は参加者から事前に自発的なインフ オームド・コンセントを得なければならない。イン フォームド・コンセントでは参加者に簡潔でかつ容 易に理解できるように情報を提供する必要がある. インフォームド・コンセントにおいて参加者が参加 することの意味を現実的に評価し，参加の可否に関 して十分な情報を得た上で決断することができるよ うに，参加者に対して，目的，参加の意味，予測さ れるリスク及び利益，収集する試料及びデー夕の種 類，機密性及びプライバシーを保護するために使用 する手順及び保護手段，結果のフィードバックに関 する方針，試料及びデー夕の保存及び保存期間，同 意を撤回する権利及び行使する方法等について十分 な情報を提供しなければならない。そのために，イ ンフォームド・コンセント資料は，参加者が理解可 能で，明瞭・簡潔・平易な言葉で記載されるべきで ある。また，よくある質問への回答や質問の問い合 わせ先に関する情報についても容易にアクセスでき るようにすべきである.

人々の健康に対する関心やニーズの高まりは，近 年，目覚しいものがある，産官学，市民，社会が協 力することにより，ファーマコゲノミクスが促進さ れ，医療が向上するだろう。ファーマコゲノミクス
が市民権を得て一般化するには専門家による適切か つ十分な情報の提供により，市民を含む関係者の理 解が深まり，コンセンサスを得る必要がある。その ためには，科学・技術面や倫理面の解決を図ること が重要である。これらが解決されるならば実用化も 近いと予想される.

\section{3. 世界のファーマコゲノミクス研究及び制度の} 動向

国際医科学機構評議会 (Council for International Organizations of Medical Sciences; CIOMS) のフ アーマコゲノミクスワーキンググループの活動が大 きな役割を果している.

CIOMS ファーマコゲノミクスワーキンググルー プは，ファーマコゲノミクスが将来の医療，医薬品 開発，規制，社会，経済，保険システムなどに与える 影響を検討する必要性から設置され，2005 年 2 月 に 12 の章と世界の主な国の現状を紹介する annex で構成された報告書「Pharmacogenetics-Towards improving treatment with medicines」を刊行してい る. ${ }^{4)}$ CIOMS が作成する報告書は国際的な強制力 はないが，これまでに ICH などを通じて各国の医 薬品行政に影響を及ぼした例もある.

2005 年 11 月, ICH シカゴ会議においてファーマ コゲノミクスに関する非公式な会議が開かれ，フ アーマコゲノミクスに関する検討が進められ, 20) そ の結果， 2007 年 10 月の横浜会議では「ゲノム薬理 学における用語集（E15）」がステップ 4 に到達し, 2008 年 1 月に厚生労働省医薬品局より通知が出さ れている。ささらに，2008 年 4 月には「ゲノムバイ オマーカーの記載方法（E16）」がトピックとして 選定され，ファーマコゲノミクスバイオマーカーの 認定を裏付けるデー夕の種類，デー夕の収集方法や 規制当局への報告の形式（format）について議論 することになり，2008 年 5 月末から 6 月初めにか けて米国オレゴン州ポートランドで開催された専門 家作業部会ではガイドラインの記載内容，構成，書 式，今後のスケジュールなどが議論され，2009 年 秋にステップ 2 に到達を目指すことが合意され た. ${ }^{21)}$

具体的な事例は以下の通りである。FDA は 2005 年 7 月, camptosar (一般名：irinotecan）の添付文 書を改訂し，グルクロン酸転移酵素 UGT1A1 の遺 伝子多型である*28 をホモで持つ患者では campto- 
sar の用量を減量しなくては副作用が生じる危険性 が示された。蛣いて 8 月に, Invader UGT1A1 Molecular Assay が認可された. ${ }^{23)}$ なお，日本でも 2007 年 2 月に UGT1A1 遺伝子多型を判定する体外 診断用医薬品の製造販売申請が行われ，2008 年 6 月にインベーダーUGT1A1 アッセイの製造販売が

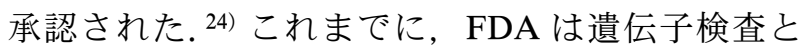
して，CYP450 の 2D6 及び 2C19 の変異を検出する Roche AmpliChip ${ }^{25)}$ 並びに HIV の薬剤耐性に係わ る変異を検出する TRUGENE HIV-1 Genotyping $\mathrm{Kit}^{26)}$ などを認可している。また，2007 年 8 月に FDA は血液抗凝固薬 coumadin（一般名：warfarin) に関してファーマコゲノミクス情報を加えた添付文 書の改訂を承認した。 ${ }^{27)} \mathrm{CYP} 2 \mathrm{C} 9$ 及びビタミン K エポキシド還元酵素複合体 VKORC1 の遺伝子に変 異がある患者は，変異がない患者と比較して， warfarin 投与量の減量が必要となる場合があること が示され， warfarin の投与法の最適化に利用される ようになっている。 2007 年 12 月に, carbamazepine の投与で，アジア人の皮膚に重篤な副作用を 生じる可能性が高いため, 投薬前の遺伝子型検査の 実施が勧奨されている. ${ }^{28)}$ HLA-B1502 タイプの患 者は原則として carbamazepine の投薬を避けること が望ましい。 6-mercaptopurine, ${ }^{29)}$ azathioprine, ${ }^{30)}$ atomoxetine ${ }^{31)}$ の添付文書においても遺伝子変異の 情報が記載されている。

FDA が公表しているゲノミクスに関するガイド ラインなどには Table 2 がある. ${ }^{32)}$ Voluntary Genomic Data Submissions (VGDS) は VXDS (X =exploratory）と拡大され，正式なバイオマーカー の的確性の認定に発展している。ささらに，FDA で は近々, Guidance for Industry, Clinical Pharmacogenetic Studies: Study Design, Data Analysis and Recommendations for Dosing and Labeling (Draft Guidance）及び Drug-Diagnostic Co-Development のガイダンスを，また，2010 年までに追加のガイ ダンスとして, End-of-Phase 2A Guidance, Adaptive Trial Guidance 及び Enrichment Trial Guidance を出す計画である. ${ }^{33)}$

また，EUでは欧州医薬品審査庁（European Agency for the Evaluation of Medical Products; EMEA) / ヒ卜用医薬品委員会 (Committee for Medicinal Products for. Human Use; CHMP) から Ta-
Table 2. Guidances from FDA

1. Guidances

- Guiding Principles for Joint FDA EMEA Voluntary Genomic Data Submission Briefing Meetings

- Pharmacogenetic Tests and Genetic Tests for Heritable Markers

- Guidance for Industry: Pharmacogenomic Data Submissions

- Pharmacogenomic Data Submissions-Companion Guidance (Draft)

- Guidance for Industry: Formal Meetings With Sponsors and Applicants for PDUFA Products

- Class II Special Controls Guidance Document: Instrumentation for Clinical Multiple Text Systems

- Class II Special Controls Guidance Document: Drug Metabolizing Enzyme Genotyping System

2. Concept Papers

- Drug-Diagnostic Co-Development-Preliminary Draft Concept Paper (4/8/2005)

- Drug Interaction Studies-Study Design, Data Analysis, and Implications for Dosing and Labeling-Preliminary Draft Concert Paper

3. Manual of Policy and Procedures (MaPP)

- Management of the Interdisciplinary Pharmacogenomics Review Group (IPRG) MaPP 4180.2

- Processing and Reviewing Voluntary Genomic Data Submissions (VGDSs) MaPP 4180.3

ble 3 のガイダンスが公表されている. ${ }^{34}$

産業界の活動としては臨床試験にファーマコゲノ ミクスを組み入れている 17 社が参加するボランタ リーな組織として Pharmacogenetics Working Group (PWG) がある. ${ }^{35)}$ 行動が必要な分野として 用語，インフォームド・コンセント，遺伝情報の開 示を取り上げ，検討結果を論文として公表してい る. ${ }^{36-40)}$

日本では医薬品医療機器総合機構（PMDA）に ファーマコゲノミクスに関するプロジェクトチーム (Pharmacogenomics Discussion Group; PDG) があ り，厚生労働省とPMDA によるファーマコゲノミ クスの活用に向けた施策を検討するための検討会も 常置されている．現在，ファーマコゲノミクスに関 連する通知及び生命倫理に関する指針には Table 4 がある。

日本でも欧米と同様に企業がコンソーシアムを作 り基盤整備を行っているいくつかの例がある．JPG コンソーシアム (Japan Pharmacogenomics Con- 
Table 3. Guidances from EMEA/CHMP

- Reflection Paper on Pharmacogenomic in Oncology

- ICH Topic E 15 Definitions for genomic biomarkers, pharmacogenomics, pharmacogenetics, genomic data and sample coding categories

- Reflection Paper on pharmacogenomic samples, testing and data handling

- Guiding principles Processing Joint FDA EMEA Voluntary Genomic Data Submissions (VGDSs) within the framework of the Confidentiality Arrangement

- Reflection Paper on the use of Genomics in Cardiovascular Clinical Trials

- Reflection Paper on the use of Pharmacogenetics in the Pharmacokinetic Evaluation of Medicinal Products

- Pharmacogenetics Briefing Meeting

- Position Paper on Terminology in Pharmaco Genetics

Table 4. Guidances from Japanease Government

1. Notifications relating to pharmacogenomics from MHLW

1) Clinical Pharmacokinetic Studies of Pharmaceuticals (June 1, 2001) ${ }^{41)}$

2) Methods of Drug Interaction Studies (June 4, 2001) 42)

3) Submitting information of clinical trials which used pharmacogenomic approaches to the regulatory agency for making the guidance of pharmacogenomic approaches on pharmaceutical development (March 18, 2005) ${ }^{43)}$

2. Guidances on Bioethics

1) Fundamental Principles of Research on the Human Genome (June, 2000) ${ }^{44)}$

2) Ethical Guidelines for Human Genome/Gene Analysis Research (April, 2004) ${ }^{45)}$

3) Ethical Guidelines for Performing Human Genetic Testing Contracted to the Japan Registered Clinical Laboratories Association (April, 2007) ${ }^{46)}$

4) Guidelines for Genetic Testing, by the Japan Society of Human Genetics, Council Committee of Ethics (August, 2003) 47)

sortium；JPGC) はファーマコゲノミクスを取り入 れた臨床試験を国内で実施するための基盤整備と国 内標準化を促進するために製薬企業が中心になり 2003 年 7 月に設立され，アスピリン服用の際の血 小板反応性の個人差と遺伝子との関連を検討する臨 床研究を実施し，その成果である「PG 試験支援 データベースシステム」の一部を一般に公開してい る. ${ }^{48)}$ また, 日本製薬工業協会は 2004 年 3 月にフ アーマコゲノミクス対応のための検討グループを発
足させ，2005 年 7 月に「医薬品の臨床試験におけ るファーマコゲノミクス実施に際し考慮すべき事項 (案) 」49)を公表し，広く意見を募集した。 そして， これらの意見を踏まえて，2008 年 3 月には「医薬 品の臨床試験におけるファーマコゲノミクス実施に 際し考慮すべき事項（暫定版）」50)を公表した。さら に，日本製薬工業協会は 2006 年 2 月からファーマ コゲノミクスの課題に関する討論会を不定期に開催 し, 関係者のコンセンサスを得てファーマコゲノミ クスの研究が推進されるよう，環境整備に努めてい る.

現在, 日本では human epidermal growth factor receptor type2 (HER2) 過剩発現が確認された転移 性乳がんに trastuzumabが使用されており，HER2 過剩発現の検查が保険収載されている。 その他, omeprazole, lansoprazole, troglitazone, imatinib mesylate, gefitinib, pioglitazone, interferon, irinotecan など多くの医薬品で臨床研究が行われている.

中国，韓国，台湾，シンガポールでは政府の強力 なサポートの下でファーマコゲノミクスの基盤整 備，研究と実用化が進められており，既に一部その 成果が上がっている. ${ }^{51)}$ 現時点ではいずれの国もフ アーマコゲノミクスに関するガイドラインなどは出 していないが，具体的な検討が始められている国も ある，倫理の重要性は広く認識されており，各国で 様々なガイドラインが出されている，また，すべて の国でシンポジウムやワークショップなどを通じて 人々の啓発が行われている. 基盤構築のための多く のプロジェクトが実施され，DNAバンクが設立さ れている国もある。既に多くの臨床試験が実施さ れ，実用化された例もある。より詳しい各国の状況 を以下に示す。

中国は生殖に関する医療面での指針はあるもの の, 生命科学研究の指針等においては未整備であ る. 臨床試験及び市販後調查は国家薬事法により規 制されている.

韓国では 2005 年 1 月に生命科学技術における生 命倫理と安全の確保を目的に「生命倫理及び安全に 関する法律」が施行された。 クローン人間の産生が 禁止されるとともにヒト胚の作成・研究利用, 遺伝 子検査, 遺伝子治療, 遺伝情報の保護・利用等が規 制されている。また，生命科学技術における生命倫 理及び安全に関する事項を審議するため，同法に基 
づき国家生命倫理審議委員会が設置されている，韓 国 FDA が認定した CYP2C9，2C19，2D6，UGT, TPMT, NAT2 の 6 つの遺伝型マーカーは韓国健康 保険審査評価院（Health Insurance Review Agency; HIRA）に承認され，その検査は健康保険の支払い 対象となっている.

台湾では「研究目的でヒト試料を採取・利用する ためのガイドライン」は作成されているが，ヒトゲ ノム/ ヒ上遺伝子研究，遺伝子検査に係わる倫理指 針はない。ファーマコゲノミクスのための血液サン プル採取及び薬物動態を左右する遺伝的多型の評価 を伴う多国間第 3 相試験及び市販後臨床試験が数多 く開始されている.

シンガポールには遺伝子検査を含む遺伝子技術の ための倫理指針がある. 2002 年に全国規模の DNA/ 組織レポジトリであるシンガポール組織ネットワー ク（Singapore Tissue Network）が設立された。国 立大学病院で行われているファーマコゲノミクス研 究の大半は遺伝的な違いが薬物応答性や疾患感受性 における人種差（中国系，白人系，インド系，マ レー系）に及ぼす影響に焦点を当てている。 2003 年から 2004 年の第一四半期にファーマコゲノミク スを取り入れた 20 件の臨床試験が製薬産業 (16 件) 及び病院/学界（4 件）より報告された。これは同 期間に保健科学庁 (Health Sciences Authority; HSA) が審査した全試験の $15 \%$ に相当する.

\section{4. ファーマコゲノミクスの実施に係わる倫理}

2005 年 4 月 1 日の個人情報保護法 ${ }^{52)}$ の全面施行 に併せて医療機関における個人情報並びに研究に係 わる個人情報の保護が図られるとともに，臨床情報 とゲノム・遺伝子解析情報の連結が必要な研究が増 加しているという研究の進展等に伴う倫理指針の見 直しが行われ，改正された倫理指針等も同日施行さ れた。 2005 年 6 月末には新指針に基づく倫理審査 委員会の設置状況等について報告を求める通知「ヒ トゲノム・遺伝子解析に関する倫理指針に基づく倫 理審査委員会の設置及び運営の状況の把握等につい て」 ${ }^{53)}$ が出された。

臨床研究に関する倫理指針 ${ }^{54)}$ の適用となる臨床研 究とは，人を対象とする（個人を特定できる人由来 の材料及びデー夕に関する研究を含む）研究であ る. 臨床研究のうち, ヒトゲノム・遺伝子解析研 究，遺伝子治療研究はそれぞれの指針を，疫学研究
のうち介入研究（手術・投薬等の医療行ためを伴う もの)は臨床研究の指針を遵守しなければならない。

ヒトゲノム・遺伝子解析研究とは提供者の個体を 形成する細胞に共通に存在し，その子孫に受け継が れ得るヒトゲノム及び遺伝子の構造または機能を， 試料等を用いて明らかにしようとする研究をいう。 研究に用いる試料等の提供等の夕が行われる場合も 含まれる。

倫理指針の見直しのほかに新たなガイドラインが 作成された，個人遺伝情報を用いる「事業」につい てもなんらかのルールが必要であるとして経済産業 省が作成した「経済産業分野のうち個人遺伝情報を 用いた事業分野における個人情報保護ガイドライ ン」, ${ }^{55)}$ 個人情報保護法の対象となる病院，診療 所，薬局，介護保険法に規定する居宅サービス事業 を行う者等の事業者が行う個人情報の適正な取扱い の確保に関する活動を支援するために厚生労働省が 作成した「医療・介護関係事業者における個人情報 の適切な取り扱いのためのガイドライン」 ${ }^{56)}$ などで ある. 同時に，改正された倫理指針並びに新しいガ イドラインを円滑に導入するために各指針・ガイド ラインの $\mathrm{Q} \& \mathrm{~A}$ 集 ${ }^{57-63)}$ が作成された.

これらの指針及びガイドラインを Table 5 にまと めた.

なお，ヒト幹細胞を用いる臨床研究に関する指針 が 2006 年 7 月 3 日付けで告示され，同年 9 月 1 日 から施行された。 ${ }^{68)}$ また，疫学研究に関する倫理指 針及び臨床研究に関する倫理指針は，その後さらに 見直しが行われ，前者は 2007 年 8 月 16 日に告示, 同年 11 月 1 日から施行, ${ }^{69)}$ 後者は 2008 年 7 月 31 日に告示， 2009 年 4 月 1 日から施行されることに なっている。

欧州では国毎に状況が異なり，かならずしもフ アーマコゲノミクスのためのサンプル収集や解析が 容易に行われている訳ではないが，いずれにして も，欧米の多国籍企業のほとんどは治験において包 括的なインフォームド・コンセントを得て試料等を 長期間保存しようとしており, ${ }^{70)}$ わが国もこの方向 に向かうのは間違いなく，インフォームド・コンセ ント, 試料の管理, 個人情報の保護等, 倫理面につ いて十分検討しておく必要がある.

CIOMS ファーマコゲノミクスワーキングループ による報告書では倫理的問題について以下が勧奨さ 
Table 5. Guidances by Japanease Government for the Medical Field Based on Enforcement of the Act on the Protection of Personal Information

\begin{tabular}{|c|c|c|}
\hline Field & $\begin{array}{l}\text { Presiding } \\
\text { ministry }\end{array}$ & Guidances \\
\hline $\begin{array}{l}\text { Medical } \\
\text { Care } \\
{[\text { general }]}\end{array}$ & MHLW & $\begin{array}{l}\text { - Guideline regarding Appropriate } \\
\text { Handling of Personal Informa- } \\
\text { tion for Medical and Nursing- } \\
\text { Care Service Providers } \\
\text { - Guideline regarding Appropriate } \\
\text { Handling of Personal Informa- } \\
\text { tion for Health Insurance Socie- } \\
\text { ties }^{64)}\end{array}$ \\
\hline $\begin{array}{l}\text { Medical } \\
\text { Care } \\
\text { [research }]\end{array}$ & $\begin{array}{l}\text { MEXT } \\
\text { MHLW } \\
\text { METI }\end{array}$ & $\begin{array}{l}\text { - Ethical Guidelines for Human Ge- } \\
\text { nome/Gene Analysis Research } \\
\text { - Guidelines for Gene Therapy } \\
\text { Clinical Research }{ }^{65)} \\
\text { - Ethical Guidelines for Epidemio- } \\
\text { logical Research }{ }^{66)} \\
\text { - Guidelines for Clincial Studies }\end{array}$ \\
\hline $\begin{array}{l}\text { General } \\
\text { Business }\end{array}$ & METI & $\begin{array}{l}\text { - Guideline regarding Act on the } \\
\text { Protection of Personal Informa- } \\
\text { tion in the Field of Economy, } \\
\text { Trade and Industry }{ }^{67)} \\
\text { - Guideline for the Protection of } \\
\text { Personal Information in the } \\
\text { Field of Business with Personal } \\
\text { Genetic Information in the Field } \\
\text { of Economy, Trade and Industry }\end{array}$ \\
\hline
\end{tabular}

MHLW: Ministry of Health, Labour and Welfare, MEXT: Ministry of Education, Culture, Sports, Science and Technology, METI: Ministry of Economy, Trade and Industry.

\section{れている.}

・ファーマコゲノミクス情報は医療情報の一部とし て捉えられるべきであり，他の医療データと全く 異質のものではない.

・全ての遺伝情報の機密性は，他の医療あるいは個 人情報と同様の厳重な保護をしなければならない.

・ファーマコゲノミクス及びその生みだす情報の意 味を理解してもらうためにも，一般及び専門家向 けの教育を大いに活発にする必要がある.

・公共政策においては，ファーマコゲノミクスデー 夕を含む全ての医療情報の不正使用を防止するた めの安全管理措置を講じなければならない.

治験と倫理について米国 FDA ではファーマコゲ ノミクスデータは，医療データの一部として捉える べきであり，別途，規制する必要はなく，現在の
GCP におけるインフォームド・コンセントと施設 内倫理委員会（Institutional Review Board; IRB）の 規定はファーマコゲノミクスについても十分対応で きると考えている. ${ }^{71)}$

日本では「ヒトゲノム・遺伝子解析研究に関する 倫理指針」に「薬事法（昭和 35 年法律第 145 号） に基づき実施される医薬品の臨床試験及び市販後調 査，または医療機器の製造，輸入承認申請のために 実施される臨床試験及び市販後調査については，同 法に基づき，既に医薬品の臨床試験の実施の基準に 関する省令（平成 9 年厚生省令第 28 号）及び医薬 品の市販後調查の基準に関する省令（平成 9 年厚生 省令第 10 号）により規制されており，本指針の対 象としない」とされている。しかしながら， GCP には新しい分野であるヒトゲノム・遺伝子解析研究 に関する記載がないことから，治験の現場では混乱 を生じている。

このため, 厚生労働省は日本臨床薬理学会ゲノム 委員会へ医薬品評価におけるファーマコゲノミクス の利用に関する現状と課題に関する調査を依頼し，

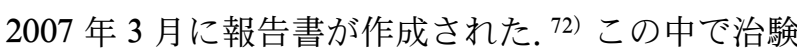
審査委員会の役割の明確化（倫理審査委員会との役 割との区別)，同意取得の方法と最低限記載すべき 情報, 適切な個人情報保護とサンプル匿名化の方 法，被験者への適切な情報開示の方法，サンプルの 長期保存に関する方法等について検討すべきとされ た.

また，日本製薬工業協会では倫理的側面から通常 の治験に付加して行うべき事項を明確化することを 目的に「医薬品の臨床試験におけるファーマコゲノ ミクス実施に際し考慮すべき事項」を作成した。こ こでは，治験におけるファーマコゲノミクス検討を 目的や時期から分類 A, B, C に分類している. 当 初, 日本製薬工業協会では分類 $\mathrm{A}$ は治験の一部と して実施されるためすべて GCP を遵守, 分類 $\mathrm{B}$, C は採血までは GCP を遵守するが保存後は「ヒト ゲノム・遺伝子解析研究に関する倫理指針」を遵守 するとした。 しかし，パブリックコメントや海外で は保存後も GCP に従うという状況を考慮し，2008

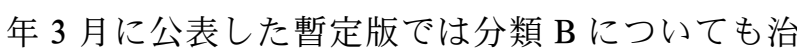
験の一部としてすべて GCP を遵守に変更した.

製薬企業が治験を実施する際の課題について日本 製薬工業協会はこれまでに 3 回の討論会を実施し, 
サンプルの長期保存に付随するインフォームド・コ ンセントや倫理審査，匿名化，遺伝情報の開示等の 課題について議論した。 2007 年 2 月に行われた討 論会「治験での遺伝情報の開示について」では 1) ゲノム解析結果は被験者から希望があれば原則とし て開示すべきである，2）被験者から非開示で同意 を得ていても，その後に被験者が開示を希望した場 合には，被験者へ結果を開示しなくてよいという理 由が明確でない限り，非開示とすることは難しい， ただし，関係者間の価值観の共有が必要であり，開 示すべきかどうかは被験者だけの権利に基づいて決 められるものでもなく, 現実(実行可能性) ・法律・ 倫理の 3 つの面から検討することが重要である，と いうことで関係者のコンセンサスを得た. ${ }^{73)}$

医薬品開発の課題を解決する手段の 1 つしてて アーマコゲノミクスに対する期待は大きく，ファー マコゲノミクスを取り入れた医薬品開発を行うため の基盤整備に向けた取り組みが進みつつある。した がって，これまで以上に医学研究や医薬品開発にお いては連結可能匿名化されたヒ卜試料と情報の取扱 いが増加し，重要になってくると思われる。GCP や倫理指針を遵守した上で適正な医学研究や臨床試 験を推進することにより，患者によりよい医療・医 薬品をより早く提供していくことが求められる.

\section{5. おわりに}

臨床試験に入った候補物質のうち $90 \%$ が開発中 止に至るため，上市される医薬品が減少し，このま までは製薬企業のパイプラインは枯渇してしまうの ではないかと危惧されている.さらに上市後 2 年以 内のラベルの変更や毎年起こる重篤な副作用による 大型製品の市場からの撤退や訴訟等，企業は多くの 課題を抱えている。，一方，医療の現場では十分に満 足されていない疾患や症状が数多く存在し, 今後も 新しい医薬品の開発が必要とされている。 さらに, より合理的, 論理的な薬剤の使用の促進や社会的, 経済的損失を防ぐことが求められている。これらの 状況を打破する 1 つの手段としてファーマコゲノミ クスが期待されている.

ファーマコゲノミクスを実用化するためには第 1 に科学的，技術的課題，第 2 に社会的，倫理的課題 を解決していく必要がある。薬剤の有効性, 副作 用，薬物相互作用等は遺伝子型に依存する場合が多 いが，すべての問題の原因が遺伝子にある訳ではな
い。しかしながら，いずれにしても，医薬品の開発 は，ジェノタイピングによる対象の選択や投与量の 適正化を行うというファーマコゲノミクスの手法を 採用する方向に向かっていくのではないかと思われ る.

これらの課題の解決に向けて日本では産官学の努 力が続けられている.

2001 年に文部科学省, 厚生労働省, 経済産業省 より「ヒトゲノム・遺伝子解析に関する倫理指針」 が出され，治験はこの指針の対象としないと記載さ れていたが，GCP にはファーマコゲノミクスに関 する記載がないため，治験の現場では混乱と負担を 生じた。また，ジェノタイピング，遺伝子情報の取 扱いについてのパブリックアクセプタンスの問題 や，承認審査での扱われ方が示されていないため に，海外の企業の取り組みの速さや規模に比較し て，日本の企業では負担やリスクの増大を危惧し， CYP2C9，2C19 及び 2D6 等のファーマコゲノミク 又臨床試験を除いては，なかなか進んでいない。一 方で日本の研究開発指向型の製薬企業のほとんどが ファーマコゲノミクスへ高い関心を持っていること は明らかである。

ファーマコゲノミクスが進展しない状況をみて, 厚生労働省は 2005 年 3 月に「医薬品の臨床試験に おける PGx の利用指針の作成に係る行政機関への 情報の提出について」を発出した。この通知はゲノ ムの検査を用いて使用される医薬品を開発するため の臨床試験等が適切に行われるよう, 臨床試験の実 施に関する指針を作成するための情報収集を目的と したものである．日本製薬工業協会ではこの通知案 のパブリックコメントの募集に際して，指針を作成 することにより基準を明確化することは，企業の判 断を容易にし，曖昧さからくる煩雑さをなくせるメ リットは大きく，歓迎したいという意見を述べた。 有効な規制は医薬品の品質・有効性・安全性を保証 するとともに，研究開発を促進する．ただし，ガイ ドラインは関連する科学の進歩に照らして見直しを 行うことも必要である。

このような行政等の動きもあり，日本でも治験に ファーマコゲノミクスを取り入れられる環境が整備 されつつある。また，国際的な整合性を図るため， CIOMS や ICH での検討が行われ，第一歩として 用語の定義が合意された。一方，産業界もファーマ 
コゲノミクスのためのインフォームド・コンセン ト，サンプルの保存，結果の開示等に関する基本的 な考え方等を明らかにしている.

日本で，より円滑にファーマコゲノミクスを利用 した医薬品開発を実施するためには国際的な整合性 についても考慮しながら，これまでの治験との差異 等を踏まえ，考慮すべき事柄を整理し，関係者のコ ンセンサスを得るための方策を検討する必要があ る。 その際，関係者の意識調査において課題とされ た情報の提供についてより具体的にどのような対象 に対してどのような情報をどのような形で提供すれ ばよいか，最適な実施方法なども検討する必要があ る.さらに，ファーマコゲノミクスについては，実 用化のための取り組みが始まったばかりであり，今 後，さらに新しい知見が得られ，また，社会に還元 されていく中で新たな課題が明らかになっていくと 予想される，このため，今後も最新の情報や動向に 注目し，整理して分かり易い形で関係者に提示し， 一歩一歩着実にファーマコゲノミクス応用の基盤を 整備していくことが重要である.

ファーマコゲノミクスの実用化に向けては今後開 発される新薬と既に市販されている医薬品，薬効と 副作用の場合等で異なる対応が必要とも考えられ, 一律に進めることは難しいと予想されるが，産官学 いずれにおいても，ファーマコゲノミクスを活用し ていくべきであるという点で意見は一致しており， 科学・技術，規制，倫理面等についてグローバルな 規模でさらに議論が深められることを期待したい.

謝辞本研究の全般に渡り，ご助言，ご指導頂 きました岐阜薬科大学薬剤学研究室平野和行教授, 東京大学大学院薬学系研究科医薬政策学津谷喜一郎 教授，独医薬基盤研究所具嶋弘監事に深く感謝いた します。

\section{REFERENCES}

1) Lander E. S., et al., Nature, 409, 860-921 (2001).

2) Venter J. C., et al., Science, 291 (5507), 13041351 (2001).

3) Lazarou J., Pomeranz B. H., Corey P. N., JAMA, 279, 1200-1205 (1998) .

4) "Pharmacogenetics-Towards improving treat- ment with medicines", CIOMS, Geneva, 2005.

5) Anon., Nat. Rev. Drug Discov., 2, 3 (2003).

6) Knowles J., Gromo G., Nat. Rev. Drug Discov., 2, 63-69 (2003).

7) Marshall E., Science, 302, 588-590 (2003).

8) 〈http://www.fda.gov/oc/initiatives/criticalpath/whitepaper.pdf $\rangle, 28$ November, 2008.

9) 〈http://www.fda.gov/oc/initiatives/criticalpath/reports/opp_report.pdf $\rangle, 28$ November, 2008.

10) 〈http://www.fda.gov/oc/initiatives/criticalpath/reports/opp_list.pdf $\rangle, 28$ November, 2008.

11) 〈http://www.pmda.go.jp/ich/e/e15_08_01_ 09.pdf $\rangle, 28$ November, 2008.

12) 〈http://www. kantei. go. jp/jp/mille/991222 millpro.pdf $\rangle, 28$ November, 2008.

13) Sumino Y., Miyagishima T., Faruaw, 36(12), 1080 (2000).

14) "2010 nen no iryouniizu no tenbou," Japan Health Sciences Foundation, Tokyo, 2001.

15) "Genomukagaku no rinshououyou ni mukete," Japan Health Sciences Foundation, Tokyo, 2003.

16) "Kiseidoukou chousa houkokusho, Regyuratorisaiensu no tenbou-Ankeitochousa ni motoduku kousatu to teigen," Japan Health Sciences Foundation, Tokyo, 2005.

17) "2015 nen no iryouniizu no tenbou," Japan Health Sciences Foundation, Tokyo, 2006.

18) Fujio Y., Tsutani K., Watanabe H., Tamaoki M., Azuma J., Jpn. J. Clin. Pharmacol. Ther., 38(4), 225-230 (2007).

19) Fujio Y., Tsutani K., Tamaoki M., Watanabe H., Masui T., Ryu S., Nukaga T., Azuma J., Jpn. J. Clin. Pharmacol. Ther., 37 Suppl, S194 (2006).

20) 〈http://www.pmda.go.jp/ich/w/2005_11chicago.pdf $\rangle, 28$ November, 2008.

21) 〈http://www.jpma-newsletter.net/PDF/2008 127_10.pdf $\rangle, 28$ November, 2008.

22) 〈http://www.fda.gov/cder/foi/label/2005/ 020571s024,027,028lbl.pdf $\rangle, 28$ November, 2008.

23) 〈http://www.fda.gov/bbs/topics/NEWS/2005 /NEW01220.html/, 28 November, 2008.

24) 〈http://www.sekisuimedical.jp/news/pdf/20 080620.pdf $\rangle, 28$ November, 2008.

25) 〈http://www.fda.gov/bbs/topics/news/2004/ 
new01149.html , 28 November, 2008.

26) $\langle$ http://www.fda.gov/CbER/seltr/K000038L. htm $\rangle, 28$ November, 2008.

27) 〈http://www.fda.gov/bbs/topics/NEWS/2007 /NEW01684.html , 28 November, 2008.

28) $\langle$ http://www.fda.gov/bbs/topics/NEWS/2007 /NEW01755.html , 28 November, 2008.

29) 〈http://www.fda.gov/cder/foi/label/2004/ 09053s024lbl.pdf $\rangle, 28$ November, 2008.

30) 〈http://www.fda.gov/cder/foi/label/2005/ 016324s030,017391s013lbl.pdf $\rangle, 28$ November, 2008.

31) 〈http://www.fda.gov/cder/foi/label/2003/21 411slr001_strattera_lbl.pdf $\rangle, 28$ November, 2008.

32) 〈http://www.fda.gov/cder/genomics/regulatory.htm $\rangle, 28$ November, 2008.

33) 〈http://www.fda.gov/cder/genomics/presentations/Lesko_PCAST_Jan08.pdf $\rangle, 28$ November, 2008.

34) 〈http://www.emea.europa.eu / htms/human/ mes/emergingtechnologies.htm $\rangle, 28$ November, 2008.

35) $\langle$ http://www.i-pwg.org/cms/ $/ 28$ November, 2008.

36) Spear B. B., Heath-Chiozzi M. E., Barnes D. M., Cheeseman K., Shaw P., Campbell D. A., McCarthy A., Ray S. C., Culver K., McHale D., Anderson D. C., Dahlstroem C., Hashimoto L., Sandbrink R., Pharmacogenomics J., 1, 101-103 (2001).

37) Anderson C., Gomez-Mancilla B., Spear B. B., Barnes D. M., Cheeseman K., Shaw P., Friedman J., McCarthy A., Brazell C., Ray S. C., McHale D., Hashimoto L., Sandbrink R., Watson M. L., Salerno R. A., Pharmacogenomics J., 2 (5) , 284-292 (2002).

38) Lesko L. J., Salerno R. A., Spear B. B., Anderson D. C., Anderson T., Brazell C., Collins J., Dorner A., Essayan D., Gomez-Mancilla B., Hackett J., Huang S. M., Ide S., Killinger J., Leighton J., Mansfield E., Meyer R., Ryan S. G. , Schmith V., Shaw P., Sistare F., Watson M., Worobec A., J. Clin. Pharmacol., 43 (4) , 342-358 (2003).

39) Salerno R. A., Lesko L. J., Pharmacogenomics, 5(1), 25-30 (2004).

40) Renegar G., Webster C. J., Stuerzebecher S., Harty L., Ide S. E., Balkite B., Rogalski-
Salter T. A., Cohen N., Spear B., Barnes D. M., Brazell C., Bioethics, 20(1), 24-36 (2006) .

41) 〈http://www.piis.pref.mie.jp/ipp/ta/index a1-2.asp?PARAM1 $=10000295\rangle, 28$ November, 2008.

42) 〈http://www.piis.pref.mie.jp/ipp/ta/index a1-2.asp?PARAM1 $=10000296\rangle, 28$ November, 2008.

43) 〈http://www.piis.pref.mie.jp/ipp/ta/index a1-2.asp?PARAM1 $=10002074\rangle, 28$ November, 2008.

44) 〈http://www.mext.go.jp/a_menu/shinkou/ seimei/gensokuj.pdf $\rangle, 28$ November, 2008.

45) 〈http://www.mext.go.jp/a_menu/shinkou/ seimei/genome/04122801.htm $\rangle, 28$ November, 2008.

46) 〈http://www.jrcla.or.jp/info/info/dna190401. pdf $\rangle, 28$ November, 2008.

47) 〈http://www.mext.go.jp/a_menu/shinkou/ seimei/genomeshishin/05062701/003/001.pdf $\rangle$, 28 November, 2008.

48) $\langle$ http://www.tri-kobe.org/pg/index.html \# $\rangle$, 28 November, 2008.

49) 〈http://www.okusuri.org/ $/, 12$ September, 2008.

50) 〈http://www.jpma.or.jp/about/basis/guide/ pdf/phamageno.pdf $\rangle, 28$ November, 2008.

51) Tamaoki M., Gushima H., Tsutani K., Pharmacogenomics, 5(8), 1023-1027 (2004).

52) 〈http://www.kantei.go.jp/jp/it/privacy/houseika/hourituan/>, 28 November, 2008.

53) 〈http://www.mhlw.go.jp/general/seido/kousei/i-kenkyu/rinsyo/dl/shishin.pdf $\rangle, 28$ November, 2008.

54) 〈http://www.mhlw.go.jp/general/seido/kousei/i-kenkyu/rinri/0504sisin.html , 28 November, 2008.

55) 〈http://www.meti.go.jp/policy/bio/index. html $\rangle, 28$ November, 2008.

56) 〈http://www.mhlw.go.jp/topics/bukyoku/ seisaku / kojin / dl / 170805-11a.pdf $\rangle, \quad 28$ November, 2008.

57) 〈http://www.mhlw.go.jp/general/seido/kousei / i-kenkyu / genome / 0504qa.html $\rangle, 28$ November, 2008.

58) 〈http://www.niph.go.jp/wadai/ekigakurinri/ q-and-a.htm $\rangle, 28$ November, 2008.

59) 〈http://www.imcj.go.jp/rinri/main/04qa_top. 
htm \# top $\rangle, 28$ November, 2008.

60) 〈http://www.mhlw.go.jp/topics/bukyoku/seisaku/kojin/dl/170805iryou-kaigoqa.pdf $\rangle, 28$ November, 2008.

61) 〈http://www.mhlw.go.jp/topics/bukyoku/seisaku/kojin/dl/170331kenpoqa.pdf $\rangle, 28$ November, 2008.

62) 〈http://www.meti.go.jp/policy/it_policy/privacy/q\&a.htm〉, 28 November, 2008.

63) 〈http://www.meti.go.jp/policy/bio/seimei-rinri/files/toiichiran.pdf $\rangle, 28$ November, 2008.

64) 〈http://www.mhlw.go.jp/topics / bukyoku/ seisaku/kojin/dl/161227kenpo.pdf $\rangle, 28$ November, 2008.

65) 〈http://www.mhlw.go.jp/general/seido/kousei/i-kenkyu/idenshi/0504sisin.html $\rangle, 28$ November, 2008.

66) 〈http://www.mhlw.go.jp/general/seido/kou- sei/i-kenkyu/ekigaku/0504sisin.html >, 28 November, 2008

67) 〈http://www.meti.go.jp/feedback/downloadfiles/i40615hj.pdf $\rangle, 28$ November, 2008.

68) 〈http://www.mhlw.go.jp/bunya/kenkou/iryousaisei.html $\rangle, 28$ November, 2008.

69) 〈http://www.mhlw.go.jp/general/seido/kousei/i-kenkyu/ekigaku/0504sisin.html , 28 November, 2008.

70) $\langle$ http://www.cmr.org/institute/ $\rangle, 28$ November, 2008.

71) Arnold H. P., MsHale D., Pharmacogenomics, 7 (2) , 149-155 (2006).

72) 〈http://www.pmda.go.jp/topics/file/h191113 kohyo.pdf $\rangle, 28$ November, 2008.

73) Watanabe K., JPMA News Lett., 119, 22-24 (2007). 